Фаріон, Ірина. «Штрихи до біографічно-ідеологічного портрета Святослава Караванського». Лінгвостилістичні студії, вип. 14, 2021, с. 144-54.

Farion, Iryna. "Some Strokes to the Biographical and Ideological Portrait of Sviatoslav Karavanskyi". Linguostylistic Studies, iss. 14, 2021, pp. 144-54.

удк 81'272(092)

https://doi.org/10.29038/2413-0923-2021-14-144-154

\title{
ШТРИХИ ДО БІОГРАФІЧНО-ІДЕОЛОГІЧНОГО ПОРТРЕТА СВЯТОСЛАВА КАРАВАНСЬКОГО
}

\author{
Ірина Фаріон \\ Національний університет «Львівська політехніка», \\ Львів, Україна
}

У статті вперше розглянуто окремі особливості біографічно-ідеологічного портрета відомого українського мовознавця і політика Святослава Караванського (1920-2015). Простежено цілісність націоналістичного світогляду мовознавця, нескореного понад 30-річним ув'язненням московським тоталітарним режимом та 37річним перебуванням на еміграції. Аналіз здійснено на основі двох основних максим мислителя, науковця і борця: історичної і соціолінгвальної.

Ключові слова: історична максима, соціолінгвальна максима, біографічноідеологічний портрет , мовно-національна свідомість, мовна політика.

\section{SOME STROKES TO THE BIOGRAPHICAL AND IDEOLOGICAL PORTRAIT OF SVIATOSLAV KARAVANSKYI}

\author{
Iryna Farion \\ Lviv Polytechnic National University, Lviv, Ukraine
}

The article elucidates specific features of the biographical and ideological image of the famous Ukrainian linguist and politician Sviatoslav Karavanskyi (1920-2015). The study seeks to identify the integrity of the nationalist worldview of the linguist that developed in the conditions of more than 30 years of restraint by the Moscow totalitarian regime and 37 years of emigration. The analysis has been conducted in terms of two principal conceptions of the thinker, scientist, and fighter: historical and socio-lingual. Under the current socio-political conditions, the topicality and appropriateness of the socio-lingual methodology of the linguist and politician are coherent.

Ukrainian lingual and historical truth is interpreted by the linguist and politician against the background of the American-European strategies concerning the aggressorcountry Moscow and the newly-established independent state of Ukraine. According to S. Karavanskyi, the issue of the official status of the Ukrainian language is identical to the Ukrainian statehood existence and, vice versa, any preferences given to the Russian language imply a return of Ukraine to the colonial status. That is, Ukrainian and Russian languages in Ukraine are two political poles: independence and colonialism, statehood and statelessness.

In the focus of his judgments are activities of prominent and equally distinguished figures of our history - T. Shevchenko, S. Bandera, and R. Shukhevych. They are considered as

(C) Фаріон I., Волинський національний університет імені Лесі Українки, 2021.

Це стаття відкритого доступу на умовах СC BY-NC 4.0 
a litmus test for the national maturity of the Ukrainians themselves and an approach to explain the European structures' irritation caused by a fear of a new competitor in the heart of Europe. The linguist's main criterion of perceiving the global and the national is the crosscutting concept of truth substantiated in his publicist works and regarded by him as a unique thing we have and fight with. In this man, heroic history of almost a century is woven with a pervasive Ukrainian nation ideal - to be in its otherness.

Key words: historical maxim, sociolingual maxim, biographical and ideological image, lingual and national consciousness, language policy.

Вступ. Біля начал вивчення портретів українських мовознавців стоїть видатний науковець і публіцист Ю. Шевельов, у поле дослідження якого потрапили такі знакові постаті українського мовознавства, як О. Потебня, В. Сімович, К. Михальчук, В. Ганцов, О. Курило. Він слушно вважав, що Доба Розстріляного Відродження потребує не лише грунтовних персоналістичних літературознавчих розвідок, але поряд із відкриттям заборонених та знищуваних мовознавчих праць слід розкривати і долі видатних мовознавців крізь призму їхніх мовно-світоглядових переконань та ідейного трибу часу. Із далекого закордоння він зазначав: «Наш обов'язок - говорити тут те, чого там сказати не можна; спростовувати неправду, яка часом шириться звідти; не давати в міру наших сил згаснути тому вогневі, який там запопадливо згашують...» (Шевельов 6). Саме такою постаттю, що 3 магаданського ув'язнення та американської еміграції не давала згаснути вогневі мовної правди і був Святослав Караванський, який фактично заклав своїми працями основи сучасної культури мови та суттєво спричинився до мовно-національного відродження на межі XX - XXI століття. На сьогодні (крім епізодичних спогадів його побратимів та коротких передмов до його виданих праць Пошук 3; Різників 5) не маємо ні тематично окремого, ні цілісного дослідження життєпису С. Караванського i його мовознавчої та письменницько-перекладацької спадщини, що $є$ винятковим матеріалом для соціолінгвістики, лінгвоперсонології та історії і культури мови.

Об'єктом нашого дослідження $є$ біографічно-ідеологічний портрет видатного українського мовознавця i суспільно-політичного діяча C. Караванського та тлі його неспинної боротьби за національний розвиток української держави в часи тоталітаризму і відновлення державної незалежности.

Мета дослідження - розкрити знакові біографічні дані та ідейні переконання С. Караванського крізь призму тоталітарного режиму i відновленої Української Держави, а також довести потребу та злободенність застосування соціолінгвальних констант мовознавця i політика в теперішніх суспільно-політичних умовах.

Матеріали і методи дослідження. Основними матеріалами для дослідження послужили окремі праці мовознавця, які він написав на еміграції, але більшість із них надруковано в Україні у 2000-і роки: «Пошук українського слова, або Боротьба за національне “Я”» (2001), «Словник рим 
української мови» (2004), «Лист до героя пера - Марії Матіос. Листи, статті, інтерв’ю і таке інше» (2013), «Книга-журнал одного автора» (2010) та ін. Основний метод нашого дослідження - описово-аналітичний, що базується на аналізі численних статей, інтерв'ю та окремих праць автора з метою застосувати їхні ідеї в теперішній мовній політиці та впливати на формування мовно-національної свідомости.

Результати дослідження та дискусія. Поодинокими є постаті у світовій та нашій культурі, коли служіння національній ідеї рівновелике і в суспільно-політичному, і науково-мистецькому житті. С. Караванський (24.12.1920-17.12.2016) яскравий цьому приклад. Він, мабуть, єдиний, що для вияву своєї поліфонійної життєтворчости вдався до унікальної друкованої новації - різножанрової книги-журналу, «щоб там була і проза, i поезія, і п'єси, і гумор, і переклади; і все одного автора» (Караванський, Книга-журнал 4) - і все це наскрізь пройняте еталонною вимогою вдосконалення нашої мови та національно-державного гарту.

Майже столітній шлях пройшла ця героїчна й нескорена людина i зуміла за 68 років примусового й віддаленого перебування від батьківщини і рідної мови зберегти канон цієї мови і служіння рідній землі (Фаріон 21). Йому вдалося зробити неможливе: крізь бетон понад 30-ох років московсько-сталінських концтаборів і 37-ох років американської еміграції він виніс перла нашої мови на поверхню, що спричинилося до суттєвих процесів деколонізації української мови та мовно-національної свідомости. Його праці з проблем культури мови, правопису, словники, прозові, поетичні та перекладні твори стали основою мовнонаціонального відродження початку 90-их років XX століття.

Мабуть, не випадково він взявся перекладати знаменитий віршманіфест англійського патріотизму Р. Киплинга «Коли» («If»), бо сповна зреалізував його умовний спосіб послань до нескореної і непереможної людини:

Коли ти змусиш нерви, серще, м'язи

Твоїй меті служити завжди й скрізь

І не відступиш навіть в тому разі,

Як всі вони благатимуть: «Спинись!»

Він не відступився від своїх переконань за жодних умов від часу вступу в березні 1942 року в Одесі до лав ОУН(б) під псевдом «Бальзак», назвавши себе «рядовим ОУН», до засудження його 7 лютого 1945 року Одеським військовим трибуналом за націоналістичну діяльність на 25 років, а відтак до повторного його засудження (без суду і слідства) 13 листопада 1965 року, щоб добувати термін 8 років і 7 місяців.

Під час цього ув'язнення Караванський п'ять разів оголошував голодування. Різними способами він через свою дружину передавав протестні заяви та свідчення, які озвучували у світових засобах масової інформації: «Стосувалися ці заяви національного питання в СССР <...: 
ішлося про утиски та злочини проти українців, поляків, прибалтів, а також гебреїв...» (Караванський, Лист 215).

Упродовж другого арешту, що насправді став добуванням його попереднього терміну, влітку 1969 року його арештовують знову: «Мене засуджено за поширення правди про Катинь на десять років, і за совєтською системою сполучення двох вироків мені додано шість років до мого першого строку» (Караванський, Лист 170), - себто вже під час ув'язнення ця героїчна людина збирала свідчення в'язнів про розстріл польських офіцерів у Катині росіянами, а не німцями. 1972 року за антиукраїнську пропаганду й поширення самвидаву засуджують на чотири роки його дружину - Ніну Строкату. Після відбуття покарання її примушують мешкати в Тарусі Калузької области (Росія). 9 листопада 1976 р. вона стає членом-засновником Української Гельсинської Групи.

Щойно 1979 року завершується термін ув'язнення Святослава Караванського - він приїздить до дружини і також стає членом УГГ. Радянська влада позбавляє подружжя громадянства, але чи можна було їх позбавити України та національних переконань. Про це С. Караванський напише у вірші, присвяченому дружині як передслові до знаменитого «Словника рим української мови» (Караванський, Словник рим III):

Коли на суд віків та внуків

Збереться наша вся сім'я,

I з колом слова та науки

Тихенько зайдеш ти і я -

Там, знай, хвалитись буде кожен:

«Я те зробив...Я те сказав...».

Ти ж мовиш просто: «В час безбожний

Душі моєї враг не взяв» (1968р.)

«Чому мене й дружину витурили з СССР, було для мене самого загадкою», - згадує нескорений оунівець. Проте збір подальших фактів дозволяє зробити висновок: постійно через дружину передавав заяви, що лунали з радіостанцій «Свобода» та «Голос Америки; у заявах ішлося проти національних утисків поляків, прибалтів, українців, гебреїв. Відтак з Нью Йорку надійшов виклик на виїзд до Америки, але виїхати могли лише на ізраїльську візу. Дружина отримала виклик до Ізраїлю через те, що свого часу С. Караванський написав статтю про обмежувальну норму вступу гебреїв до вишів в СРСР. Цю єдину статтю опубліковано в «Нью ріпаблік». Себто Караванського сприйняли за гебрея i, зокрема, з огляду на прізвище: «Гадаючи, що на захист гебреїв міг виступити тільки гебрей, ці достойники зробили можливим виїзд захисника гебреїв Караванського на «гнилий «Захід» (Караванський, Лист 178, 215; Фаріон).

На закордонні, в чужомовному середовищі, С. Караванський створює свої основні мовознавчі праці: Практичний словник синонімів української мови, 1993 (2-5-е вид. 2000, 2008, 2012, 2014), «Секрети української мови...», 1994, Російсько-український словник складної лексики, 1998, 2-е 
вид., 2006, «Пошук українського слова, або Боротьба за національне “Я"», 2001, Словник рим української мови, 2004, «До зір крізь терни, або Хочу бути редактором», 2008, «Звідки пішла єсть московська мова або Шила в мішку не сховаєш», Львів, 2014, «Ідіотизми сталінської ярижки у державній мові України», Львів, 2016.

Усі ці праці пройняті наскрізною ідеєю «реставрації національних рис» («це лише пращя збирача і заразом писаря» - Караванський, Книгажурнал 105) української мови та прагненням донести до українців правду про їхню історію та мову, знищувану і спотворену в часи окупації СРСР: «Я тільки відтулив краєчок завіси, за якою сховано незліченні багатства» (Караванський, Книга-журнал 105). Поза активною мовознавчою та письменницькою i перекладацькою діяльністю «рядовий оунівець» провадить дуже активну суспільно-політичну роботу, що випливає з його цілісного націєцентричного світогляду, сформованого ще в 30-40-і роки XX століття і кристалізованого до останніх митей життя. Саме цей світогляд маємо намір показати крізь призму двох основних ідеологічних максимів історичної та соціолінгвальної.

\section{Історична максима: «Нема історії України - значить нема} України» (Караванський, Лист 78).

Основний засіб війни 3 історією і з сучасністю - брехня. Нашою найосновнішою зброєю у війні з фінансово потужним ворогом $є$ «Слово Правди. Вони ж правди ой як не люблять. Вони знайшли напівбожевільного фанатика-ненависника (ідеться про міністра освіти в 2010-2012 рр. Д. Табачника - I. Ф.) і поставили його вчити Наших дітей, щоб учив їх Неправди, щоб те, що біле, звав чорним, а те, що чорне, - білим» (Караванський, Лист 102). У «Відкритому листі до п'ятої колони» політик зазначає, що правда, для ворога «гірше від пістолета»: «Ви не можете кроку ступити, щоб не брехати. Але слово правди було, $є$ й буде сильніше від брехні». Відтак С. Караванський наводить саркастичний парадокс, від якого ворог вужем звивається: «Ви всіма фібрами своєї чорної душі ненавидите українського пророка Т. Шевченка. Чому? Бо Шевченко - це Бандера, а Бандера - це Шевченко. I ви знаєте це, та хоч і знаєте, мусите вдавати із себе шанувальників Шевченка, тобто шанувателів Бандери» (Караванський, Лист 105).

Від сучасного протиборства правди - брехні С. Караванський перекидує місток до недавного історичного минулого. Він наголошує, що московській машині не вдалося морально знищити бандерівського руху, тому вона вдалася до тотального оббріхування цієї політичної сили, як і петлюрівщини. На жаль, правдиві документи читають «десятки або сотні, а брехню - тисячі й мільйони» (Караванський, Лист 86), що призвело до викривленого сприйняття українського націоналістичного руху в Европі, зокрема, постаті Степана Бандери: «Що герой Европи, який разом із лісовими братами Прибалтики стояв в обороні европейських ідеалів після своєї героїчної боротьби, яка зміцнила Европу і послабила імперію новітніх 
Чингиз-ханів, замість бути визнаним борцем за незалежність Европи $i$ Польщі в тому числі, зазнає несправедливих і безпідставних наклепів» (Караванський, Лист 86).

Мовознавець наводить переконливу паралель про тотожність духу Т. Шевченка, С. Бандери, Р. Шухевича: «Та ж Шевченко був бандерівцем XIX століття» (Караванський, Лист 81) і риторично запитує 3 нагоди святкування 200-ліття Шевченкового ювілею: «Як можна святкувати Шевченка і бризкати слиною на втілювачів ідей Шевченка - Степана Бандеру, Романа Шухевича та героїчну УПА?» (Караванський, Лист 81).

Щодо скасування звання Героя України С. Бандері, тобто «суду пігмеїв над велетнями» (Караванський, Лист 83) - слушно запитує, «чи ж має права зватися Героєм України той, хто проголошував і проголосив нашу незалежність» 30 червня 1941 року у Львові в умовах Другої Світової війни і «боротьби двох світових хижаків за право володіти Україною»? (Караванський, Книга 111). Нема сумніву, що сліпа ненависть ворогів України до її величних героїв лише надасть їм ще більшої сили: «Кричіть! Волайте! Репетуйте! Убезсмертюйте наших героїв навіки!» (Караванський, Лист 84). Понад то, С.Караванський наголошує : «Рух ОУН зазнав реальної поразки у нерівній битві з диктатурою Кремля, але цей рух переміг морально» (Караванський, Лист 85).

Водночас мовознавець 3'ясовує причини надвеликої кількости жертв, покладених у боротьбі за свою державу. Таємна поліція большевиків - ЧК, НКВД, КГБ - мала такий колосальний ужинок жертв тому, що була «категорія убогодухих громадян», що «за шмат гнилої ковбаси» виконували всі злочинні забаганки ворога (Караванський, Книга 99). Він звертає увагу на виняткову шкідливість «колишніх христопродавців», що «стають завзятими патріотами» лише на словах - «цей прошарок ниций, непевний $i$ nідступний» (Караванський, Книга 99). 3 висоти свого надскладного історичного досвіду мовознавець намагається достукатися до збаламученого теперішнього населення України і вказати йому, що «проімперські клани не хочуть ні України, ні їі самостійности.... Але вони підступно вдають із себе патріотів України, щоб захопити владу і віддати наш край на поталу ворогам» (Караванський, Книга 111).

Пронизливий історичний погляд кидає С. Караванський на таку необ'єктивно хвалену в сучасному суспільстві Европу, використовуючи заїжджений та оманливий політичний термін «европейські цінності». Гострим лезом свого розуму політик розтинає всю европейську фальш, справедливо історично урівнюючи Европу з Росією в поневоленні і знищення інших народів: «Згадаймо лише Бартоломіївську ніч, спалення на вогнищі Жанни д’Арк, Джордано Бруно, Яна Гуса, не кажучи про тисячі безіменних жертв, спалених або потоплених. У ХХ віці Европа порадувала світ появою двох найдикіших і найнелюдяніших режимів: СССР і Третього Райху. Той факт, що ті режими ніби зникли з лищя Европи, ще не свідчить 
про те, що «цінності» такого трибу не блукають привидом по Европі» (Караванський, Лист 96).

Мовознавець використовує паронімну антитезу поневолювача / поневоленого, які будуть у протистоянні доти, поки міжнародне право не викреслить зі свого поля протиборчі взаємини межи народами, що насправді рівні перед вічністю. У цьому контексті він дуже вміло, переконливо і стилістично вишукано апелює до надскладних українськопольських стосунків, у центрі яких постать С. Бандери, до якого має претензії Европарламент у своїй резолюції «Про ситуацію в Україні» (2010) - чи мають право ті, що творили криваву історію, вчити українців, кого обирати за героїв?

С. Караванський блискуче оперує законом детермінізму, логічно вказуючи, що терористична діяльність ОУН - це наслідок дискримінаційної політики поляків щодо українців і риторично запитує: «Хто більше винен за акт геноциду щодо поляків, що стався на Волині під час війни: місцеве населення під проводом ОУН чи Ю. Пілсудський, який поселив на Волині польських колоністів?» (Караванський, Лист 97). Цей закон причини і наслідку мислитель поширює на боротьбу сербського, ірландського та чеченського народів зі своїми імперськими поневолювачами Австро-Угорщиною, Великобританією і Росією.

Закон детермінізму політик поширює i на сучасне угодовське ставлення Америки (йдеться про президентство Обами в 2009-2017рр.) до Росії, потураючи їй в агресії проти України і Грузії та призводячи такими нечесними і протиправними діями до світової кризи і можливости Третьої світової війни: «Чи віддання України та Грузії на поталу агресору зміцнить демократію у світі, чи навпаки сприятиме утвердженню тероризму як норми у відносинах між державами?» (Караванський, Лист 112).

Соціолінгвальна максима: «уся українська самостійність і сталася через мову» (Караванський, Лист 94).

Мовознавець слушно наголошує, що боротьба 3 українською незалежністю почалася 3 того, «що російські царі завзялися зробити 3 України «Юго-Западный край». I почали з мови. Боротьба українців за право послуговуватися своєю мовою це й була боротьба українців за незалежність. I всі колонізатори України починали колонізувати Україну з мови, забороняючи й переслідуючи українську мову» (Караванський, Лист 72). Відтак Кремль під маркою класової боротьби насправді завжди провадив національну боротьбу (Караванський, Лист 75).

Політична самостійність України без розвитку української мови як державної - фікція: «Державність української мови - це і є суть нашої самостійности. Саме через мову і сталося проголошення самостійности України» (Караванський, Лист 89).

Основним засобом спотворення дійсности та брехні виступає слово. Біблійний апостол Яків людський язик називає «вогнем пекельним» i «світом неправди»: «Язика ж ніхто з людей не може вгамувати: він зло, що 
спокою на знає, наповнений смертельною отрутою» (Святе Письмо 286). Мовознавець наголошує на його основній номінативній функції: «...коли не дати антидержавним поглядам правильної назви, ці погляди сприймаються як цілком «державні», бо ніхто їх не назвав правильно» - i щиро обурюється, коли, до прикладу, націоналістичну партію «Свобода» називають ультра-націоналістичною хіба тільки за те, «що вона боронить права упослідженої у своїй державі нації?» - і це тоді, коли цього префікса не застосовують до тих, хто порушує Конституцію, плює на демократичні свободи: «їхні дії не «ультра-узурпаторські», не «ультра-зрадниџькі», не «ультра-продажні», не «ультра-злочинні?» (Караванський, Лист 89).

С. Караванський, спираючись на низку сучасних та історичних прикладів, наголошує на основній номінативній функції слова, що моделює реальність: «Правильна назва фактів і подій - запорука від усяких несподіванок та ворожих збігів. Вона помагає нам правильно оцінювати подіï й факти життя» (Караванський, Листи 90). Як тут не згадати Конфуція, який казав, «якщо мова не є правильна, то вона не означає того, що має означати; коли ж вона не означає того, що має означати, то не буде зроблене те, що має бути зроблене; а тоді моральність і всяке мистецтво почнуть занепадати, справедливість зійде на манівці - і всі впадуть у стан безладу» (Радевич-Винницький 198).

Особливим контекстом соціолінгвальних максим С. Караванського $\epsilon$ його ставлення до російської мови та її місця в українській історії. Спираючись на статтю 10 Конституції України про «вільний розвиток, використання і захист російської, інших мов національних меншин України», мовознавець наголошує на неприпустимості державного статусу російської мови, бо це «ліквідує нашу самостійність» і повертає Україну в «колоніяльні стосунки» (Караванський, Лист 90, 94), звідки переконливо випливає основна націє- і державотвірна функція мови. Політик цілком слушно вмотивовує відкладення планованого перепису населення 2012 року спробою підвищити статус російської мови в Україні, позаяк перепис аж ніяк не спрацював би на користь щоразу меншої «російської нацменшини», а отже, непохитність державного статусу лише однієї мови української (перепис 2001 року: українців 37.541.693, росіян: 8.334.141, інших: 2.385.068) (Караванський, Лист 98-99).

3 огляду на аналізоване, очевидною $є$ збережена впродовж років гострота політичного зору С. Караванського та його ідеологічно випробувана часом націєцентрична позиція. У своїх численних відкритих листах до української влади та европейських інституцій мовознавець і політик маніфестує принципову національну та державницьку позицію, спираючись передусім на історичну максиму про правдиву історію як запоруку існування національної держави та соціолінгвальну максиму про державність української мови як запоруки нашої незалежности.

Заглиблюючись в історичні та соціолінгвальні максими, мовознавець констатує надскладний стан сучасного суспільства: «Сьогоднішня Україна 
бачиться як рана. Велика кровоточива рана. Сили України підточує егоцентризм, вождизм, заздрість до успіхів однокашників, невміння орієнтуватися в людях, невміння реально оцінювати, хто є хто не на підставі слів, а на підставі вивчення біографії особи: що ти робив, голубе, коли нас нищили? Ці хиби пояснюють масове зрадництво депутатів нібито проукраїнського табору» (Караванський, Лист 183). Як завжди, його політична прозірливість іде в парі 3 чіткими екзистенційнонаціональними порадами розв'язання наших мовно-політичних проблем:

- що має спонукати людину говорити українською? «Національна гордість. Коли ї̈ немає, ніщо людину не спонукає, бо людина без національної гордости - це щось дуже далеке від людини» (Караванський, Лист 185);

- $з$ чого почати вчити мову сьогодні? «Читати класиків, почавши 3 Шевченка, Котляревського, Марка Вовчка, Ганни Барвінок, Нечуя-Левицького» (Караванський, Лист 185);

- українізацію України слід починати з армії, законів про державну службу та освіту: «Головний наголос треба робити саме на освіту» (Караванський, Лист 189).

На твердження журналіста, що в добу постмодернізму і глобалізму націонал-демократична риторика застаріла, С. Караванський відповів безапеляційно: «Застаріла?! Це вам, либонь, кажуть пропагандисти імперських націй, націй, які пригноблювали та обкрадали «менших братів». Але для окрадених «братів» національно-демократичні погляди - чи не єдиний рятунок у світі, загрузлому у «злому злі» (Караванський, Лист 217).

Висновки. Відбувши 31 рік московсько-сталінських тюрем та заслань і провівши на американській еміграції 37 років, ця героїчна людина зберегла і розширила цілість свого націоналістичного світогляду і продовжувала боротьбу вже в Незалежній Україні за iї деколонізацію, деокупацію і повернення до питомих національних джерел мови та історії.

Українську мовно-історичну правду мовознавець і політик розглядав на тлі американсько-европейських стратегій щодо країни-агресора Москви і новопосталої української незалежности. Питання державного статусу української мови, за його міркуваннями, тотожне самій державності України, натомість будь-які преференції для російської мови - це повернення України в колоніяльний статус. Себто українська та російська мова в Україні - це два політичні полюси: незалежність і колоніяльність, державність і бездержавність.

У центрі його суджень видатні і рівновеликі постаті нашої історії Т. Шевченко, С. Бандера і Р. Шухевич як лакмуси на національну зрілість самих українців й характерні подразники в европейських владних середовищах як страх перед новопосталим конкурентом в самому осерді Европи. Основним мірилом сприйняття глобальної та національної політики мовознавця $є$ наскрізний у його публіцистичних працях концепт правди - те єдине, що ми маємо і з чим «виходимо на бій», залишаючи 
відкритим запитання: «То хто візьме гору в цьому бою? Брехня чи Правда? Вони чи Ми?» (Караванський, Лист 103).

Так у цій людині яскраво виткано героїчну історію майже столітнього плину з наскрізним українським ідеалом - бути у своїй іншості: «Голодомор про це свідчить: нас нищено за нашу іншість. Така $\epsilon$ правда історії» (Караванський, Лист 104). Подальше дослідження життя видатного мовознавця торкатиметься його мовознавчої спадщини, аби у висліді подати цілісний портрет науковця і політика, що пройшов «до зір крізь терня» удержавлення нашої мови.

\section{Список використаних джерел}

Караванський, Святослав. Пошук українського слова, або, Боротьба за національне «Я». Київ: Видавничий центр «Академія», 2001.

Караванський, Святослав. Словник рим української мови. Львів: БаК, 2004.

Караванський, Святослав. Книга-журнал одного автора. Львів: БаК, 2010.

Караванський, Святослав. Лист до Героя пера - Марії Матіос. Листи, статmі, інтерв'ю $i$ таке інше. Львів: БаК, 2013.

\section{Sources}

Karavanskyi, Sviatoslav. Poshuk ukrainskoho slova, abo, Borotba za natsionalne "Ia". Kyiv: Vydavnychyi tsentr "Akademiia", 2001.

Karavanskyi, Sviatoslav. Slovnyk rym ukrainskoi movy. Lviv: BaK, 2004.

Karavanskyi, Sviatoslav. Knyha-zhurnal odnoho avtora. Lviv: BaK, 2010.

Karavanskyi, Sviatoslav. Lyst do Heroia pera - Marii Matios. Lysty, statti, interviu i take inshe. Lviv: BaK, 2013.

\section{Список використаної літератури}

Радевич-Винницький, Ярослав, й Іванишин, Василь. Мова і нація. Тези про місце і роль мови в національному відродженні України. 6-те вид. Львів: Апріорі, 2012

Різників, Олекса. «Таке буває раз на 100 років». Слово Просвіти, ч. 2, 14-20 січня 2021, с. 5

Святе Письмо старого і нового завіту. Повний переклад, здійснений за оригінальними єврейськими, арамійськими та грецькими текстами. Ukrainian Bible DC, United Bible Societies, 1991.

Шевельов, Юрій. Портрети українських мовознавців. Київ: Видавничий дім «КМ Академія», 2002. 132 с.

Фаріон, Ірина. «Святослав Караванський: біографічний портрет у профіль». $M u$ пам'ятаємо. Електронний лінгвомеморіальний альманах. Матеріали круглого столу Всеукраїнської науково-практичної інтернет-конференції «Проблеми філології: історія та сучасність», 19 лютого 2021 року, м. Хмельницький. Хмельницький, 2021, с. 21-5.

\section{References}

Radevych-Vynnytskyi, Yaroslav, and Ivanyshyn, Vasyl. Mova i natsiia. Tezy pro mistse $i$ rol movy $v$ natsionalnomu vidrodzhenni Ukrainy. $6^{\text {th }}$ ed. Lviv: Apriori, 2012.

Riznykiv, Oleksa. "Take buvaie raz na 100 rokiv". Slovo Prosvity, ch. 2, 14-20 Jan. 2021, p. 5.

Sviate Pysmo staroho i novoho zavitu. Povnyi pereklad, zdiisnenyi za oryhinalnymy yevreiskymy, aramiiskymy ta hretskymy tekstamy. Ukrainian Bible DC, United Bible Societies, 1991.

Shevelov, Yurii. Portrety ukrainskykh movoznavtsiv. Kyiv: Vydavnychyi dim "KM Akademiia", 2002. 
Farion, Iryna. "Sviatoslav Karavanskyi: biohrafichnyi portret u profil". My pamiataiemo. Elektronnyi linhvomemorialnyi almanakh. Materialy kruhloho stolu Vseukrainskoi naukovo-praktychnoi internet-konferentsiii «Problemy filolohii: istoriia ta suchasnist», 19 liutoho 2021 roku, m. Khmelnytskyi. Khmelnytskyi, 2021, pp. 21-5.

Стаття надійшла до редколегії 15.04.2021 